\title{
ARE WE NAÏVE TO THINK WE CAN SAVE RARE PLANTS FROM EXTINCTION?
}

\author{
David A. Burney ${ }^{l}$
}

\begin{abstract}
In places such as the Hawaiian Islands, where over half the native flora may be at risk of extinction in coming decades, the criticism is sometimes raised that the situation is so hopeless that the talents, energy and money of botanical gardens and other plant conservation organizations is largely wasted in trying to save these plants. Although stories of failure abound, it is important to recognize that considerable progress is being made. Organizations such as the National Tropical Botanical Garden (NTBG) have led the way in this eleventh-hour effort, not by naïvely pursuing failed strategies, nor by pulling back and only pursuing very limited goals, but by approaching the huge challenges with an energetic pioneering spirit. By taking an innovative comprehensive approach, dealing with the crisis at the level of ecosystems and plant communities rather than merely individual species, NTBG and other organizations are making progress on a broad front that integrates a range of scales and techniques and adapts to the shifting circumstances through careful monitoring and a spirit of optimism that is coupled with scientific scepticism.
\end{abstract}

\section{INTRODUCTION}

At a meeting of department heads and administrators of the National Tropical Botanical Garden (NTBG) recently, the subject turned as it often must, to setting priorities for conservation of the highly endangered local flora versus the many other aspects of the organization's mission, including science and education. In these uncertain financial times in particular, such discussions are naturally charged with a degree of emotion, as all aspects of garden operation and outreach must ultimately include some belt-tightening.

Perhaps feeling disappointment at the outcome of the discussion, one member of staff made a sotto voce comment that "It's naïve to think that we can save most of these plants." It was all I could do to pretend to ignore the comment, which cuts right to the heart of what many of us in the room have dedicated our lives to doing, or at least trying to do.

As a paleoecologist and conservationist who has studied extinction events in the fossil and historical record around the world for over three decades in the hope of finding clues to a way out of the current biodiversity crisis, it was hard to hold my tongue, but I did. "Call it what you will. For one who has studied extinction for a lifetime like myself, it would be unethical to just do nothing when it is happening all around me", I wanted to say, but I said nothing. I thought about it plenty, though, and continue to do so because it is an important question, and it is important to know if that is the way many of my colleagues in horticulture, botany, and ecology feel.

${ }^{1}$ David Burney is Director of Conservation at the National Tropical Botanical Garden. Address: 3530 Papalina Road, Kalaheo, HI 96741 USA

Email: dburney@ntbg.org 
I couldn't help thinking to myself, as I pondered this challenge over ensuing days and weeks, of something one of my graduate school mentors told me once in the midst of a discussion about intramural sniping: "When the Devil designed torment for college professors, he came up with a good one in the form of the colleague in your same institution who claims to know more about your research than you do."

\section{THE HUBRIS OF TRYING TO STOP A MASS EXTINCTION}

What about it? Are we being foolish to try so hard to do something admittedly no humans have done before - to step into the midst of a mass extinction and try to stop it, or at least slow it down? It is probably more cost-effective and success more certain to concentrate just on plants and animals that are potentially at risk, and make sure they never become rare in the first place - pick fights we can win, that is. In places where the situation is as dire as it is in Hawaii, Mauritius, Madagascar and New Zealand, the list is fairly long. Perhaps we otherwise run the risk of going the route of the biblical story of the shepherd who abandoned his 99 secure sheep to go off looking for the one that was lost, putting all in peril? Only in the case of the flora of these countries, the ratio might be more like 50:50.

On the other hand, is it not possible that we can devise strategies to find the 'lost sheep' that also benefit the rest of the herd? Some of us think so. Before we try to answer definitively, let's take stock of our herd. Hawaii, often branded the 'Extinction Capital of the United States', is an example that stands out in high relief, but the situation is similar on many remote tropical islands, as well as in insular habitats on the continents such as tropical dry forest, isolated montane and wetland communities, cave faunas, and coral reefs.

The Aloha State represents a mere $0.2 \%$ of the land area of the United States, but contains about $40 \%$ of all Federally-listed endangered plants, and the number will probably be climbing with upcoming listings. Yet this number is misleadingly low, as Wagner et al. (1999) estimate that over half the entire flora, more than 500 species, may be at risk. In other words, as many or more species than are officially listed may in coming years or decades disappear from the planet while waiting in the queue. We have a few heartbreaking cases in which species here have apparently gone extinct, in the wild at least, before even being officially named (Brown, 2007). The situation for animals is similar, and the parallels to other islands are striking, with the more geographically remote, ancient, and diverse the landmass, the greater the percentage of losses, and with humans and their commensals at the center of it all (Burney and Flannery, 2005).

Some confessions are in order. Clearly what we have been doing in conservation in Hawaii and similar places has not been enough. Some experts believe more of the same will not necessarily alter the balance sheet much, if at all (Duffy and Kraus, 2006). Although classic in situ techniques will always be the front line of conservation, striving to save species where they are found today, there are some deficiencies that need 
to be acknowledged. In Hawaii, most rare plants today are found only in the remotest, steepest places. Habitats may be expensive to reach (think helicopter rental at the current rate of $\$ 1120$ per hour) or dangerous enough that our legendary field botanists visit them only while dangling on a rope (Fig. 1). The fossil record (Burney et al., 2001) shows clearly for species after species, not just of plants but also land snails, birds, and insects, that this phenomenon is a human artifact - these rare species don't necessarily prefer such places, it is just that these places are the only part of their once extensive range that goats, pigs, rats and a host of other invasive species cannot quite reach.

Such sites are not only expensive to maintain as a habitat, in many cases the problems that led to rarity have gone unabated. If a rare plant is visited less than once a year, how can we hope to give it the protection it needs? Conversely, how much and what kind of attention would be too much? In addition, if this is one of the last strongholds for a species,

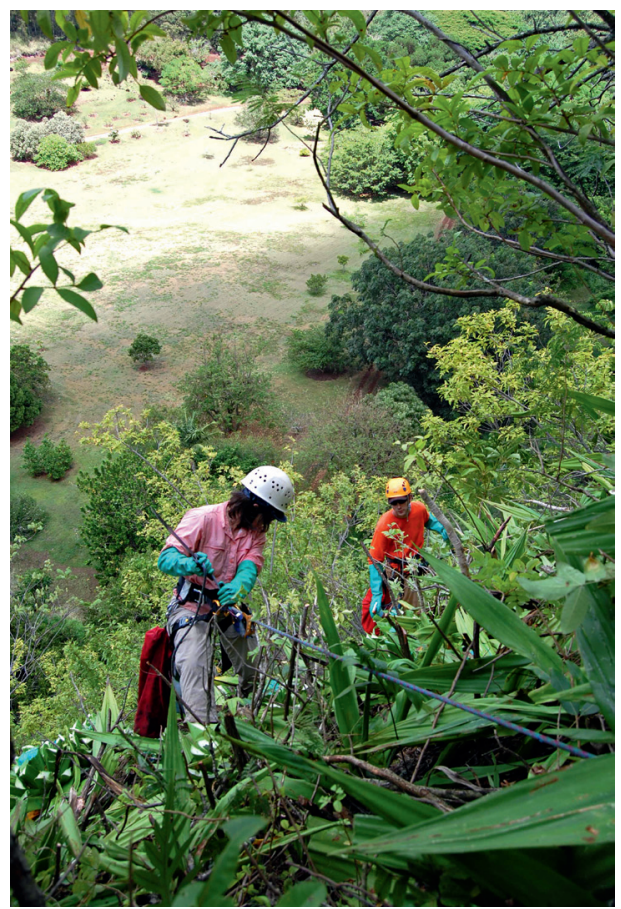

Fig. 1 NTBG Field Botanist, Natalia Tangalin (left foreground) and Limahuli Preserve Restoration Manager, Emory Griffin-Noyes (right, background) do horticulture chores on a rope $40 \mathrm{~m}$ above McBryde Garden. This cliffside restoration provides the only known habitat for the last population of an endemic chickweed variety, Schiedea spergulina var. leiopoda. Photo: Clay Trauernicht.

as is the case with so many in our flora, how do we know that this is even optimum habitat? Many of our present-day cliff dwellers (Fig. 2) may be literally and figuratively barely hanging on there, as they once may have grown in richer soils and more sheltered locations long since converted to farmland (much of which is now abandoned in the wake of Hawaii's failed agricultural economy and just growing a short list of invasive cosmopolitan weeds).

NTBG and their conservation partners, including the State Division of Forestry and Wildlife (DOFAW), the US Fish and Wildlife Service, The Nature Conservancy, and the various branches of the military so well-represented in Hawaii, are doing their best to meet the huge challenges of in situ restoration. Ungulate-proof fences are playing a role, despite their unpopularity with hunters and other local residents, and their sometimes questionable effectiveness with insufficient maintenance and concomitant weed control (Cabin et al., 2000). All these partners are building longer, higher, and more secure fences. NTBG will in the next few weeks be completing a fence over $8 \mathrm{~km}$ long around the entire Upper Limahuli Preserve of north western Kauai, a relatively 


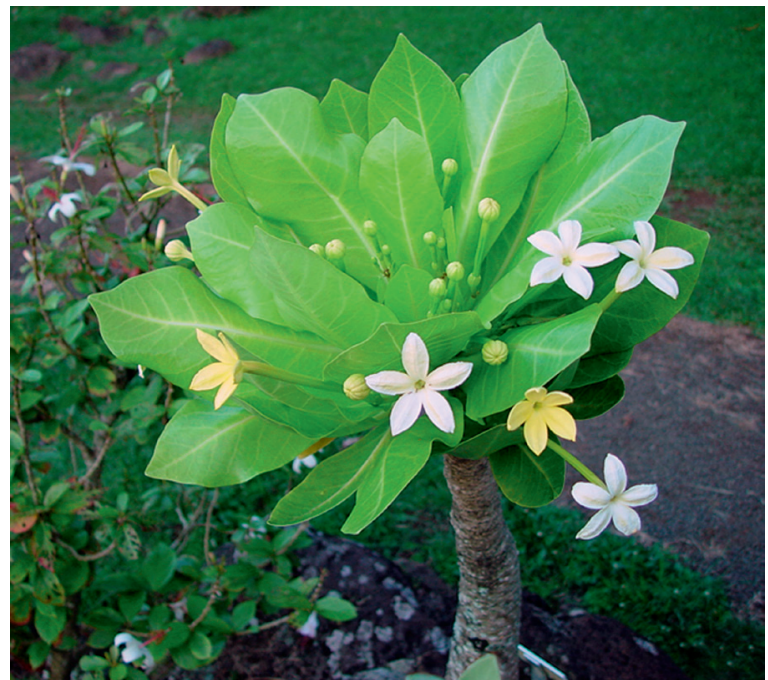

Fig. 2 The beautiful endemic bellflower Brighamia insignis grows well in our ex situ and inter situ projects. On the last in situ check only one live plant was found, clinging tenaciously to a vertical cliff. Photo: NTBG Archives.

pristine site. This is no picnic, with over 100 helicopter sling-loads of fence material, $\$ 600,000$ US in construction and materials, over three years of paperwork before the first fence post went in, and constant worries that the fence itself can be a threat. There is the possibility that the fence provides a corridor for weeds to invade and could be a strike hazard for Hawaiian Petrels and Newell's Shearwaters, two of Hawaii's most endangered seabirds which nest on the ground nearby. Fences are important, but we cannot fence in, or out, everything that needs our attention to save this flora. To think so is indeed naïve.

Other aspects of in situ conservation pose challenges, too. To return to the biblical sheep analogy once again, we do have a strategy for the lost or nearly lost species that shows signs of working. Drawing attention to the most lost of the sheep can attract money (although not nearly enough to do the job so far) that would never be available for the rest of the herd. This is what conservationists call a 'fine filter' approach, focusing resources on just certain rare elements of the ecosystem (examples are given in Soule, 1986). With the partners listed above, NTBG has embarked on a program that concentrates only on the most endangered of the endangered, 199 species at the last count represented by 50 or fewer individuals in the wild. This Plant Extinction Prevention Program (PEPP) is bringing expert attention to these languishing species through a protocol of intensified monitoring and management of these tiny populations. Clearly, this multi-institutional program administered by DOFAW recognizes that what might work for ordinarily rare species (a few hundred individuals) might not work at all when the entire wild population consists of one or a few individuals in one or a few populations that are in most cases highly disjunct today. Formerly many 
have had interpopulational gene flow based on the larger ranges of fossil occurrence. Technical arguments, unfortunately based on little or no empirical evidence, typically turn around poorly known genetic factors such as whether to risk outbreeding depression by rejoining these separate gene pools or to face the virtual certainty of inbreeding depression by keeping them separate. Much research is needed, yet this research is not being done for financial reasons, manpower limitations, and, most ironically, regulatory considerations. By the time the necessary research is done, many of these species will almost certainly be extinct.

The dedicated staff of the state-supported PEPP program, which originated with the efforts of senior field botanists at NTBG Steve Perlman and Ken Wood, includes young energetic protégés of these two. Steve and Ken, and perhaps upcoming NTBG Field Botanist Natalia Tangalin, can honestly say they probably were the last people on earth to see some now-lost species. "How many more sad stories of the 'last plant' will there be?" is now the burning question.

\section{IS THE ARK SINKING?}

Although NTBG and other botanic gardens and arboreta in Hawaii have played a big role in the development and implementation of in situ strategies, they have also been the primary players in what has traditionally been almost the exclusive province of botanic gardens worldwide, ex situ plant conservation. The living collections of NTBG include more than 100 at-risk Hawaiian plant species. I like to tell visitors to our McBryde Garden on Kauai's south shore that, as far as I know, the less than five hectares of our Native Section of the Garden contain more endangered species than any comparablesized area in the United States. But have we 'saved' these species? Nearly two dozen species of native Pritchardia palms adorn a lovely textured sweep of McBryde Garden, but most are outside their proper habitat, having been brought from all elevations, rainfall regimes, and islands of the archipelago to this one mesic spot situated in the worn-out soil of a sugar cane field abandoned three decades ago. Propped up by the subsidies of irrigation water, fertilizer, and integrated pest management, they are alive here, but only in the sense that a tiger in a zoo is. They are alive as individuals, but they are mostly lost to Nature. Seeds from these individuals, even with careful bagging, artificial pollination, and well-timed collection, are at serious risk of genetic pollution from their adjacent congeners that would never have the chance to cross in a wild situation but might, and certainly do, in the 'plant zoo'.

And what of evolution? In this botanical welfare state, plants can quickly become domesticates, and collecting from wild material may ultimately become impossible as extinction strikes in situ. Yet these living collections' descendants' genotypes may have adapted to the loving care of dedicated gardeners and are likely to drift farther and farther off the evolutionary track that hundreds of thousands or even millions of years have defined for these species. All botanic garden curators know this limitation, but I am constantly reminded by comments from visitors that the public is less aware 
of this problem, and I am conflicted in even pointing this out to actual and potential donors.

Speaking of money, those of us who have to raise the funds and balance the books for these ex situ programs know all too well that space will always be limited on this Ark. No matter how big, the boat just isn't big enough to hold all the rare plants of the world. Take in too many, and we risk sinking the entire enterprise.

Other ex situ strategies that are the stock in trade of a modern botanic garden face similar limitations. Hawaii has only a few seed banks, notably at Lyon Arboretum and NTBG, and increasingly seed banking has become important to federal efforts from the National Park Service to the Army. Space is less the limitation than in living collections, but we are greatly hampered by a shortage of trained personnel and the specific knowledge of the optimum seed storage techniques for each of hundreds of rare species whose seed dormancy characteristics have hardly been studied at all. Working with Dr. Christina Walters of the National Center for Genetic Resources Preservation, based in Ft. Collins, Colorado, Margaret Clark of NTBG has continued the effort started by Alvin Yoshinaga of Lyon Arboretum to test the viability of a wide range of rare native plant seeds under various storage regimes (for example refrigeration vs. freezing) for a range of time periods up to a decade or more. This information, already well-known in many other parts of the world, is still scarce for rare Hawaiian plants and other remote island floras.

Micropropagation efforts have focused rightly on growing the rarest plants, especially the demographically challenged (for example those with no viable seed, only one sex available, no wild plants remaining). These high-tech options offer promise but are certainly one of the most expensive options per species. Nellie Sugii of Lyon Arboretum has been the leading pioneer in this specialization in Hawaii, and NTBG is also branching into this area. This is by far the most costly solution per species, however, and NTBG has had only limited luck in establishing these in vitro plants in the wild, as they are often difficult to 'harden off' sufficiently for the rigors of a tropical climate.

Nursery production of rare native plants is another botanic garden speciality. Until recently, this was mostly a small-scale operation. NTBG has led the way in scaling up this effort. Opened in 2005, NTBG's Conservation and Horticulture Center (Fig. 3) has turned native plant production into, if not an art, certainly an industrial skill. NTBG Assistant Director of Living Collections and Horticulture, Mike De Motta, and Nursery Manager, Bob Nishek have undoubtedly propagated more native Hawaiian plants than anybody ever has. But they would be the first to admit that, with some new acquisitions never grown in a pot before, meeting the plant's requirements has to be educated guesswork. Our current inventory shows over 22,000 specimens, the vast majority native, growing in our glass house, shade house, and sunny nursery. Over the past 12 months, we set out more than 12,000 plants, quite a few of them rarities. Where do all these plants go, and what happens to them after they go into the ground?

This has historically been the weakest link in the chain that ideally starts with the collection of vouchered propagules, followed by accessioning to our comprehensive 


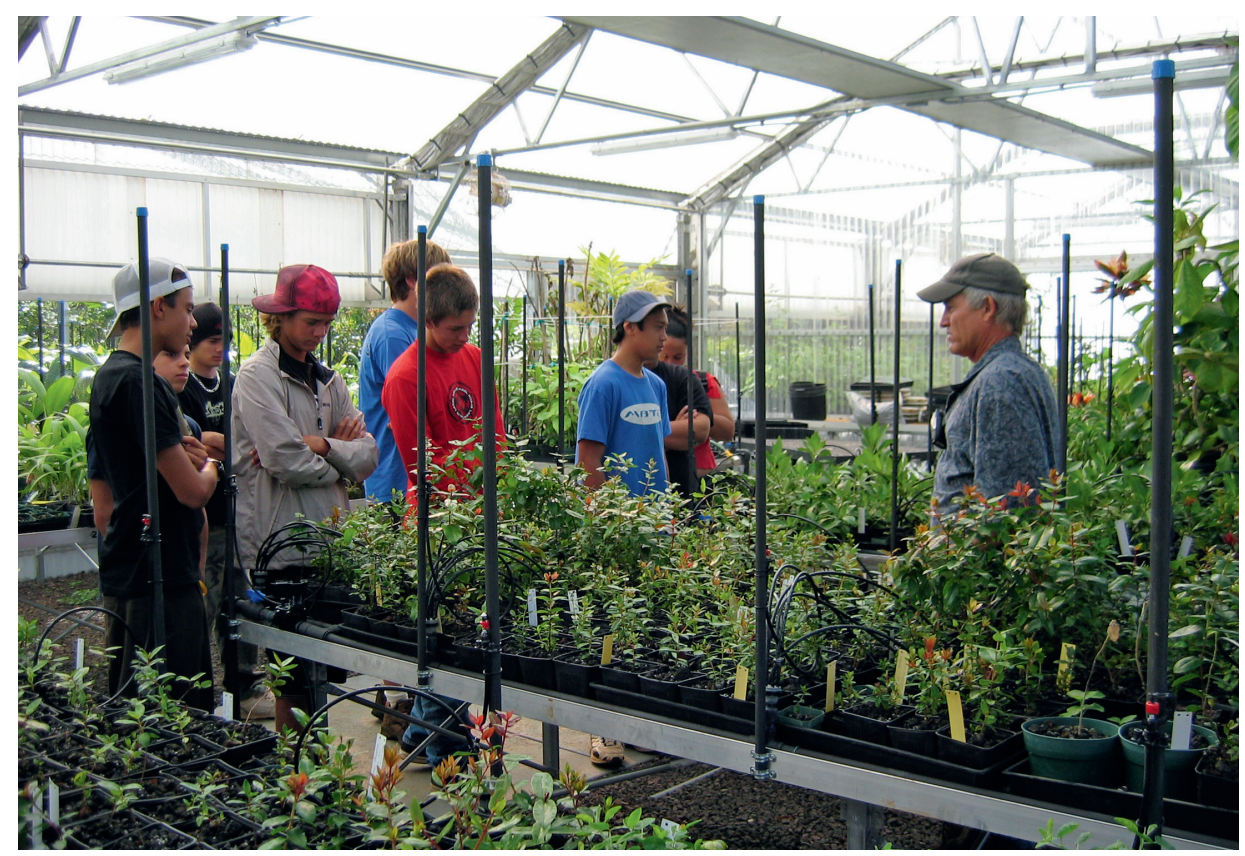

Fig. 3 In the glass house at NTBG's Conservation and Horticulture Center, Nursery Manager, Bob Nishek shares horticultural secrets with local high school pupils. Photo: David Burney.

database, which contains computer fields for collector, location, inferred parentage, and many other relevant parameters. For rare plants, metal tags are generated that will hopefully stay with the plant for many years. Propagation may take the form of sowing seed, taking cuttings, or in extreme cases, tissue culture. Finally, the plants are ready to go into our living collections, restoration sites, and nature preserves.

We have come up with some potential short cuts in what is admittedly the long road to restoration. For specifics, see Burney \& Burney $(2007,2008)$. Reintroduction of rare plants, like all restoration activity, is not likely to be meaningful unless critical numerical thresholds are passed, parameters we can only guess at. Adding three more plants to a world population of three is not likely to solve the problem. Adding 30, with as much genetic diversity captured as possible, is a little better perhaps. Even 300, though, is hardly much insurance unless the eggs are in more than one basket, that is, not just new individuals but new populations are created.

\section{INTESTINAL FORTITUDE NEEDED}

This 'scaling up' process, like all thinking big, requires, frankly, not just experience but guts. One has to be willing to fail in order to succeed in bold new ways. This is where it is important to consider that, between the two disparate ways of doing conservation, in situ and ex situ, there is a broad grey area that holds great potential for breaking out 
of the paralytic orthodoxy that conservation has so often slipped into. If we are really going to succeed where conventionality has failed, we must reject, in the words of poet Dylan Thomas: '...dry Authority, smug in its modest imaginings.' It is in the rarified atmosphere of thinking well outside the box that we might get from being merely naïve to discovering something new and useful.

German philosopher, Arthur Schopenhauer pointed out a century ago that all new ideas must pass through three stages. First they are ridiculed, later violently opposed, and finally, acknowledged as self-evident. To the surprise of some smugly experienced colleagues, the consternation of some environmental regulators, and ultimately the acceptance by the majority of the conservation community, NTBG has been at the vanguard of what some believe is a whole new way of doing conservation in Hawaii. A 'third front' has been opened in recent years, through horticultural experimentation at Makauwahi Cave Reserve, a uniquely rich fossil site surrounded by abandoned farmlands just $9 \mathrm{~km}$ eastward up the beach from NTBG headquarters (Burney \& Burney, 2008).

My wife Lida Pigott Burney and I have a license from the landowner, Grove Farm Company, to manage seven hectares at Maha ulepu that includes the largest limestone cave in the Hawaiian Islands, and surrounding areas of coastal dunes, rocky headlands, and worn-out farmland used for sugar cane and maize, and abandoned for half a decade. Lida manages the site, and has turned the degraded landscapes into a prototype for demonstrating six kinds of native plant restorations while managing the cave with its ongoing paleoecological investigations and a precious subterranean ecosystem containing at least three highly endangered invertebrates - blind amphipods, isopods, and spiders. This project is supported by its own Federal grants and community volunteers. More than 5000 native plants have been established out there since 2004, and Lida has purchased many of them from NTBG's Conservation and Horticulture Center using grants from Federal agencies to Makauwahi Cave Reserve. Virtually every local student from fourth grade up has worked with Lida to plant and maintain the restorations (Figs. 4-6), and assist us with the digs in the cave for the fossils of plants and animals from before humans, during Polynesian times, and right up to the present (Levy, 2008).

Calling the suite of techniques inter situ conservation, which is not a new term (referred to in Blixt, 1994; Guerrant et al., 2001) but a somewhat expanded usage, we have promoted the idea that progress can be made in plant conservation through techniques that are not exactly conservation 'in nature' nor classic botanic garden activity either. These techniques are more akin to the 'rewilding' movement of the western United States, where wolves and bison are making a stunning comeback. Both governmental agencies and private landowners such as entrepreneur Ted Turner have accomplished these feats of conservation. This has been done not primarily by focusing on increasing the size of existing wild populations, as important as that is, nor by breeding more in zoos, a conspicuous but scientifically dubious strategy that is nevertheless popular with the general public, but by something more or less midway between. These and other creatures such as the black-footed ferret and perhaps someday the California condor, are making a comeback primarily through a broad third front - 


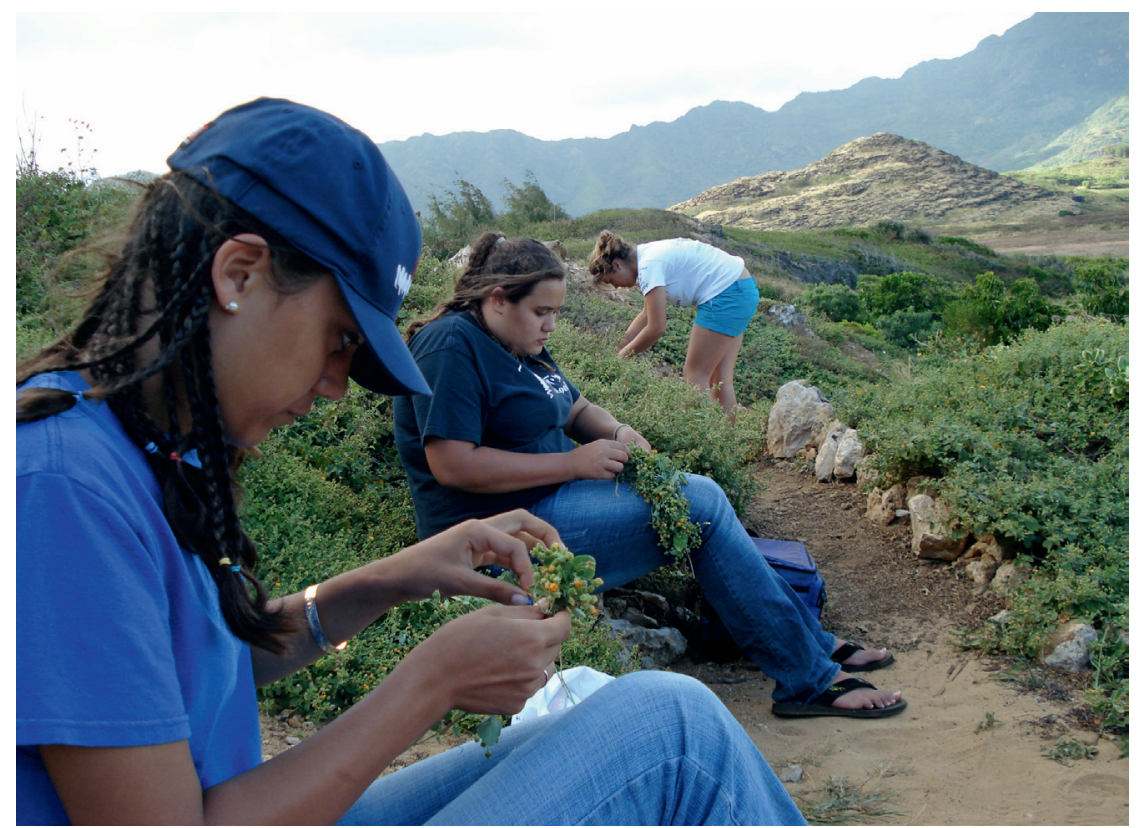

Fig. 4 In Management Unit 5C at Makauwahi Cave Reserve, a hula halau group taught by Kumu Sabra Kauka makes leis for a performance from the yellow-orange flowers of a native plant in the cotton family, ilima (Sida fallax). Photo: Sabra Kauka.

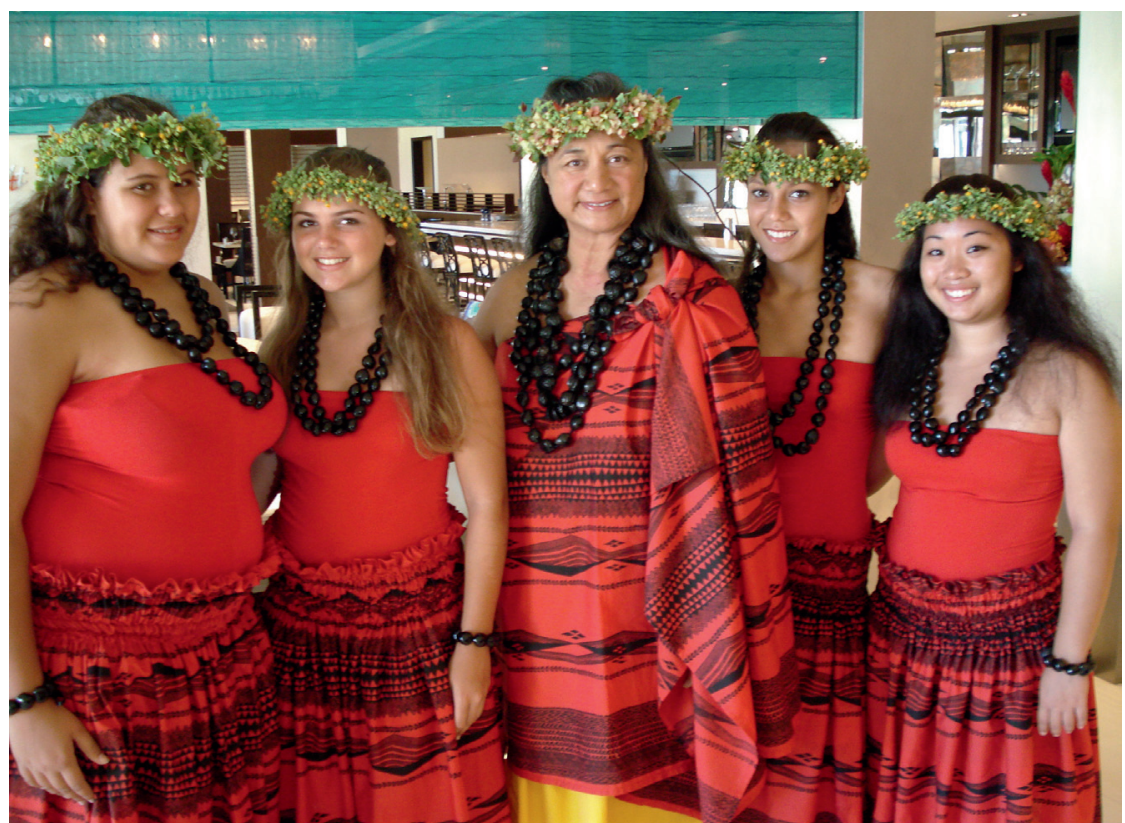

Fig. 5 Kumu Sabra Kauka (centre) and her students, model new leis from ilima flowers gathered in the Makauwahi Cave restoration. Photo: Sabra Kauka. 


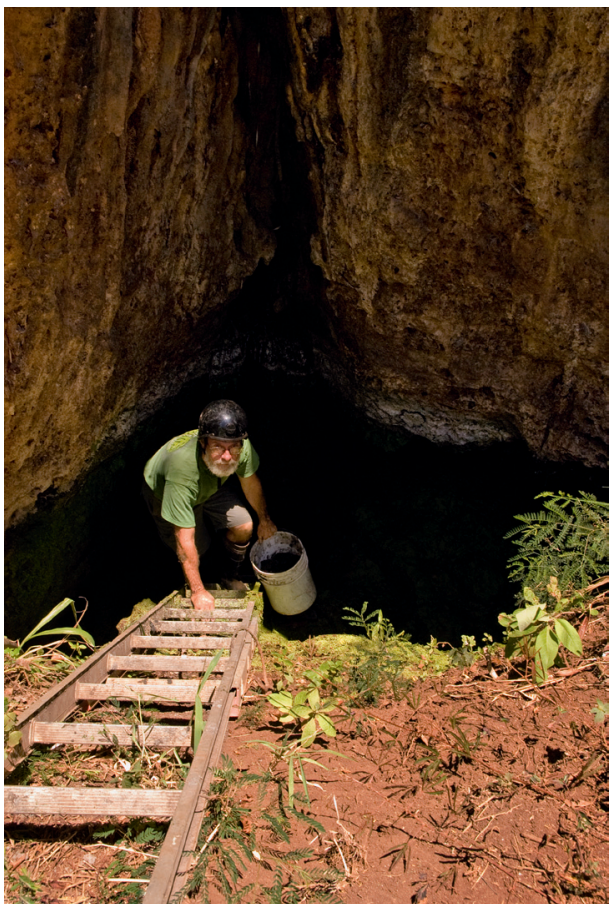

Fig. 6 Dr. David Burney climbs out of an excavation pit in the floor of Makauwahi Cave with a bucket of sediment containing fossil clues to the original vegetation of the site. This evidence has provided information for the design of the large-scale plant restoration projects at this and other locations on Kauai. Photo: Alec Burney. creating new populations in the formerly larger historical or late prehistoric range of the species (Donlan et al., 2005 and 2006). These 'rewilded' individuals usually find their way back to nature through 'soft release' programs whereby the translocated animals are kept in large enclosures in suitable natural or restored habitat - generally part of the historical range in which they were extirpated by humans decades or centuries ago, then allowed to 'escape' through a door left open when deemed ready.

In Hawaii we are trying to do something similar with plants. Although we thought that we might be the first to attempt a rewilded island flora, I discovered several years ago in my travels that the island nation of Mauritius in the midst of the Indian Ocean is already well along on similar strategies. The Mauritian Wildlife Foundation, already noted for their rewilding of the Mauritian Pink Pigeon through 'soft release', has been very successful recently in re-establishing rare native coastal trees on their preserves using rewilded tortoises as weeders. Dr. Owen Griffiths, a biologist and private landowner with ecotourism reserves on Mauritius and on the neighbouring island of Rodrigues, has restored hundreds of acres of native forest with inter situ techniques. His efforts have created many jobs in the local community, and his tortoise reserve on Rodrigues Island is adjacent to a large limestone cavern containing fossils of the extinct biota of the landscape he is restoring. Sound familiar?

The inter situ arsenal contains many strategies. It is not a single approach at all, but more a conservation philosophy. At NTBG's Limahuli Garden and Preserve on Kauai's north shore, the strategy is mostly one of 'saturate and enrich'. Limahuli Restoration Manager, Emory Griffin-Noyes and his crew use a wide array of natives, deemed appropriate on the basis of their occurrence nearby, to replace competing invasive plants removed from relatively depauperate native plant communities. We pack them in as close as we dare, in order to crowd out subsequent weed seedlings if possible. The NTBG Conservation Department uses not just native trees and shrubs, but hundreds of greenhouse-grown ferns, vines, and groundcovers - a truly three-dimensional restoration. 
In the dry rugged 'rock garden' (Fig. 4) and dune portions of Makauwahi Cave Reserve managed by Lida and her crew, and similarly in the coastal woodlands and strand at Lawai-kai in the Allerton Garden managed by NTBG, three-dimensionality is achieved by relatively 'soft' techniques. They gradually remove invasives and replace them with natives in such a manner that the area is never exposed to excessive wind, sun, and salt spray more than necessary to make the changeover. On the many hectares of flat, degraded farmland at Makauwahi, and at Iliahi, another site belonging to Grove Farm Company of south eastern Kauai, native plants are 'farmed' by removing invasives with a tractor that shreds, ploughs, and discs the land just as if sugar cane or maize were to be planted, but instead the 'row crops' consist of a thorough mixture of over 100 native species, some quite rare.

We monitor our success and failure with various horticultural and agricultural strategies through:

1. repeat photography from fixed ground stations and the air

2. taking a periodic census of the plants, recording growth rates and phenology

3. maintaining a 'cyberinfrastructure' program that measures about 30 ecological parameters in real time and is fully web-accessible (Kido et al., 2008 give examples)

These strategies include not just the customary range of weather data, but ground water levels and chemistry, deep cave environments and soil moisture. In both the 'rock garden' and the 'row crop' strategies, our careful record-keeping on weather data, plant mortality, and soil moisture shows that success is greatly increased, from survival rates as low as $10 \%$, to often over $90 \%$, by placing the plants in these drier habitats $(<1000 \mathrm{~mm} / \mathrm{yr}$ and highly seasonal $)$ on drip irrigation that is gradually withdrawn after the second summer (Burney \& Burney, 2007).

\section{THE 'ENTIRE ISLAND' TEST}

One of the ultimate tests of this battery of techniques is to attempt the restoration of an entire island - albeit relatively small. On the steep, dry, rugged 100ha islet of Lehua, just north of Niihau and across the channel from Kauai, NTBG members of staff are reintroducing more than 40 'new' species to the island, recently made entirely mammal-free with the eradication of introduced rabbits and rats. Fossil evidence, historical documents and photographs, and occurrences in similar habitats elsewhere in the Hawaiian Islands have been used to devise a list of candidates for reintroduction to the island, which contained relatively few natives after decades of ravaging by mammalian herbivores. So far, the new plants, brought to the island by helicopter and boat, appear to be thriving on the rewilded islet, thanks to the initial help of timed drip irrigation from tanks periodically replenished by adjacent rain catchments. Someday this uninhabited island may provide an appropriate refuge for some of Hawaii's rarest plants. Many natives, reintroduced 
less than two years ago, are already reproducing on their own in this relatively mammal, insect, and disease-free insular microcosm. Lehua Islet is perhaps the closest we will ever come to recreating the pristine prehistoric dry lowland environment of Hawaii, one of the state's most endangered habitat types. The next phase of the restoration calls for largescale distribution on the islet of native plant seeds grown by Niihau youth employed in a jobs program at Makauwahi Cave. They help Lida manage and harvest several hectares that are the seed source for distribution on Lehua. In the cave project's Management Unit 2 , old farmland has been converted simultaneously to a native plant reforestation project and an in-ground native-plant nursery - an inter situ strategy in which one restoration site produces the necessary propagules for others.

Perhaps someday it will be discovered that it was naïveté that ultimately saved many species in the conservation movement worldwide - perhaps including the kind that allowed the deployment and adaptation of a battery of techniques that combine the advantages of conservation in the wild and conservation in botanic gardens and zoos. One thing is clear, the smug alternative, to simply give up in the face of imposing odds, has no chance of success at all. Defeatist thinking is the shortest route to failure in this, as any, enterprise. There is only one way to find out if hope can prevail, and that is to use it to try to get something done.

The process we advocate has three parts. First, examine the history of the place, whether from fossils, historical records, oral traditions, parallels to other sites, or best of all, a combination of these. This basic respect for the lessons of the past is part of received wisdom throughout many cultures, yet it is sadly neglected in formulating many conservation strategies. Second, figure out how to scale up quickly to population sizes that can be meaningful, capturing as much genetic diversity as possible, so nature has something to work with in adapting to the site-specific challenges of survival. Third, monitor your success to the fullest extent possible, measuring everything you can. For this work to be practically viable, measures of economic, sociological and political consequences need to be included. No conservation effort can succeed without being affordable, locally acceptable, and consistent with the public will as expressed by sufficient public and private funding.

\section{PITFALL LIST}

There are some clear pitfalls that many of us have fallen into repeatedly, but we are willing to acknowledge them in the spirit of making progress.

First, don't bury your mistakes. If something isn't working, tell your colleagues, and try something else. Nobody can honestly claim to know how to do this, it hasn't been done before.

Second, studiously avoid 'paralysis by analysis'. A lot of research and monitoring has been done already. Not enough to complete our knowledge of course, but enough to 
get started doing something completely real - like collecting native plant propagules, growing them, and planting and maintaining them in appropriate places using the available science and keeping enough records to evaluate the results.

Third, don't plant and run. There are many sad little plots, some quite big actually, where well-meaning groups and individuals have planted out natives, dusted themselves off, and walked away never to return. I cannot think of a single case where that has worked in Hawaii. Most successful restorations are neither the 'howling wilderness' nor a classic botanic garden. They require follow-up care, at least for a while. It is easy to feel good about planting trees. Our projects can always draw a crowd for that. It is universally harder to get folks to come back and water, pull weeds, monitor for insects, and other such basic and essential but relatively unexciting horticultural activities. This is, I suspect, the inglorious secret to the master gardener that others imagine to have 'green thumbs'. Thumbs get green through hard work and correct timing, I always tell our horticultural interns at NTBG. Most folks aren't born with them.

Fourth, plan an exit strategy. We realize, sometimes well after it's too late, that every plant that goes into the ground is a solemn responsibility, and a distraction from every other. We generally advocate 'phased withdrawal' in that our management of native plants is aimed at gradually eliminating the need for us, once the time is right.

Fifth, everything in this business is adaptive management. Keep good records, but don't be afraid to modify or even abandon a failing protocol. Every restoration cannot be a full-blown, elegant scientific experiment in which many plants must be allowed to die in order to attain 'statistical significance'. But if we can remember what we did horticulturally, and honestly evaluate, we can make progress. We do not have to kill the plants to learn from them, and intelligent tinkering is a right many of us feel we have earned after years of pursuing scientific rigour while more and more species have become rare and died out (Cabin, 2007).

Sixth, never forget that this is a process of not just growing plants, but growing people (Burney and Dubey, 2006). Most successful restoration projects on a larger scale involve some kind of long-term community outreach commitment. Absolutely nothing is more inspiring as an educational experience than for someone to take care of another living thing, and see it grow, prosper, and make more of its kind. This is yet another reason to concentrate on restoration where people can see, enjoy and nurture it.

Seventh, help keep conservation vital by eschewing professional orthodoxy. This discipline is much too young to succumb to hardening of the arteries. Science is about scepticism and fact-based consensus, not dogma. Many good ideas in all fields, as Bayesian philosophers and mathematicians like to remind us, have to germinate out on the fringes of public or professional acceptance and grow their way toward the centre. 
Be wary of anyone in this fledgling business who claims to know how to do it (including me). Although I have been a professional conservationist of one sort or another for 45 years, starting with my job as Nature Merit Badge Counselor at Boy Scout camp at the age of 15, I am awed and frightened by how little I actually knew about it, then or now. When I think about what we thought we knew about conservation back then, versus what we know or think we know now, one of my greatest regrets is that I probably will not get to see in person what conservation looks like in 45 more years. It will not just be more of the same, I'm sure of that much.

Finally, don't let the paperwork get you down. Overzealous regulators, armchair restorationists, and obsessive theoreticians can sometimes be the greatest obstacles to success (Holling and Meffe, 1996). Like science, the law is not perfect. If it gets in the way of saving these plants, it needs to be amended or reinterpreted. Our concept of how to protect endangered species must evolve with the times, just as the species themselves must, and certainly will whether we like it or not - or go extinct. Nothing is more frustrating than to see endangered species laws, or at least people's understanding of them, discourage private landowners from participating in this great and urgent enterprise. In the western US, ranchers often boast about the 'solution' to the presence of endangered animals on their property as the 'three S's' - Shoot, shovel, and shut up. This is a tragedy that is probably borne out with rare native plants in Hawaii every day, as landowners either destroy or conceal the presence of endangered species on their property to avoid legal constraints, or even in a few celebrated cases, grow them surreptitiously as if they were cannabis or some other contraband. This is a problem with the U.S. Endangered Species Act, or at least some states' and individuals' interpretation of it, that has to be fixed, a minor glitch in an otherwise good law.

\section{STRENGTH IN NUMBERS, NAÏVE OR NOT}

Many European countries, as well as New Zealand and Australia, seem to be well ahead of the United States in addressing some of the problems outlined above. A major strategy, just now emerging in the US but well along in these other places, is that of government-NGO-private landowner partnerships. An unfortunately prevalent mentality in Hawaii and elsewhere is the notion that rare native species are the government's problem, and mostly an impediment to the private sector. That notion has to be turned around, and quickly, if this biodiversity crisis is to be averted. NTBG has led the way in this state with over a dozen such partnerships.

What we don't know yet, anywhere on earth I suppose, is whether these and other conservation strategies outlined above will buy us enough time to stop a mass extinction. We don't know, but some of us intend to find out.

So to my colleague who asks if we are naïve: I do not have a firm answer yet, but I think I have a good start on one. We may or may not be naïve, but other folks are naïve if they think some of us are not going to try our best in the face of whatever setbacks and 
criticisms confront us. There is a lot of young talent out there representing hope. Despite the current economic situation, there is some, and potentially a lot more, money and other resources for the job. We are betting on a simple goal - to keep living things alive, something they all inherently want to do anyway. Whatever the final outcome, I for one feel at once honoured and humbled - indeed even lucky - to have the opportunity to try to rise with my colleagues to this great occasion. It is above all, very satisfying to know that, however small, misguided, and insignificant in the long run our conservation efforts may have been, we gave it our best for the things we love most. As an early conservationist, US President Theodore Roosevelt said: "Far better to dare mighty things, ... even though checkered by failure, than to take rank with those poor spirits who neither enjoy much nor suffer much because they live in the grey twilight that knows not victory or defeat."

In the great immensity of time, nothing humans have done on the negative side will have more lasting impact on our precious little planet than to wipe out forever some of our fellow species. Conversely, nothing we can do in our own time will have more lasting positive influence than to save as many species as possible so that evolution, and our own civilizations, can face the future with the most diverse set of biological tools possible. Can we rise to this greatest of challenges in our time?

Yes, like the 'little engine that could' and America's new President, we think we can. After all, if we do not think we can, we definitely cannot, or at least will not. If that, my esteemed colleague, is a naïve notion, then I for one embrace it wholeheartedly anyway.

\section{REFERENCES}

BLIXT, S. (1994). Conservation methods and potential utilization of plant genetic resources in nature conservation. In: BEGEMANN F. \& HAMMER K. (Eds). Integration of Conservation Strategies of Plant Genetic Resources in Europe. IPK and ADI, Gatersleben, Germany.

BROWN, P. (2007). Where have all the flowers gone? Natural History.

BURNEY, D.A. \& BURNEY, L.P. (2007). Paleoecology and "inter-situ" restoration on Kaua i, Hawai i. Frontiers in Ecology and the Environment 5(9): 483-490.

BURNEY, D.A. \& BURNEY, L.P. (2008). Inter situ conservation: Opening a "third front" in the battle to save rare Hawaiian plants. BGjournal 6(1): 16-9.

BURNEY, D.A. \& DUBEY, E. (2006). Growing people: Community-based career development opportunities working with plants. Plant Talk 43: 46-47.

BURNEY, D.A. \& FLANNERY, T.F. (2005). Fifty millennia of catastrophic extinctions after human contact. Trends in Ecology and Evolution 20: 395-401.

BURNEY, D.A., JAMES, H.F., BURNEY, L.P., OLSON, S.L., KIKUCHI, W., WAGNER, W.L., BURNEY, M., MCCLOSKEY, D., KIKUCHI, D., GRADY, F.V., GAGE, R. \& NISHEK, R. (2001). Fossil evidence for a diverse biota from Kaua $i$ and its transformation since human arrival. Ecological Monographs 71(4): 615-641.

CABIN, R.J. (2007). Science-driven restoration: a square grid on a round earth? Restoration Ecology 15(1): 1-7. 
CABIN, R.J., WELLER, S.G., LORENCE, D.H., FLYNN, T.W., SAKAI, A.K., SANDQUIST, D. \& HADWAY, L.J. (2000). Effects of long-term ungulate exclusion and recent alien species control on the preservation and restoration of a Hawaiian tropical dry forest. Conservation Biology 14(2): 439-453.

DONLAN, C.J., GREENE, H.W., BERGER, J., BOCK, C.E., BOCK, J.H., BURNEY, D.A., ESTES, J.A., FOREMAN, D., MARTIN, P.S., ROEMER, G.W., SMITH, F.A., \& SOULÉ, M.E. (2005). Rewilding North America. Nature 436: 913-91.

DONLAN, C.J., BERGER, J., BOCK, C.E., BOCK, J.H., BURNEY, D.A., ESTES, J.A., FOREMAN, D., MARTIN, P.S., ROEMER, G.W., SMITH, F.A., SOULÉ, M.E. \& GREENE, H.W. (2006). Pleistocene rewilding: An optimistic vision for 21st century conservation. American Naturalist 168: 660-681.

DUFFY, D.C. \& KRAUS, F. (2006). Science and the art of the solvable in Hawaii's extinction crisis. Environment Hawaii 16: 3-6.

GUERRANT, E.O. JR., HAVENS, K. \& MAUNDER, M. (2004). Ex situ plant conservation: supporting species survival in the wild. Island Press, Washington, D.C.

HOLLING, C.S. \& MEFFE, G.K. (1996). Command and control and the pathology of natural resource management. Conservation Biology 10: 328-337.

KIDO, M.H., MUNDT, C.W., MONTGOMERY, K.N., ASQUITH, A., GOODALE, D.W., \& KANESHIRO, K. (2008). Integration of wireless sensor networks into cyberinfrastructure for monitoring Hawaiian "mountain-to-sea" environments. Environmental Management 42: $658-666$

LEVY, S. (2008). Lessons of a limestone cave. Wildlife Conservation Jan.-Feb. 46-51.

SOULE, M.E. (1986). Conservation Biology: The Science of Scarcity and Diversity. Sinauer Associates, Massachusetts, USA.

WAGNER W.L., BRUEGMANN M., HERBST D.R., \& LAU J.Q. (1999). Hawaiian vascular plants at risk, 1999. Bishop Museum Occasional Paper 60: 1-69. 